\title{
JEREMIAH'S COMPLAINTS
}

\section{OBSERVATIONS ON JER 15 10-21}

\author{
ERHARD GERSTENBERGER
}

YALE UNIVERSITY

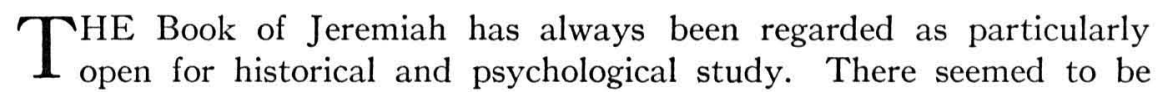
sufficient material at hand for the compilation of a biography of the prophet; his inner and outward life has even been made the subject of novels and plays. ${ }^{\mathbf{T}}$ The apparent abundance of data in Jer has exercised an irresistible temptation on virtually all scholars and commentators regardless of their school of thought or method of approach ${ }^{2}$ to focus their attention upon the prophet's curriculum vitae and experience. Jeremiah is looked upon as a religious genius, the champion of personal, inner, and spiritual religion.

The basic fallacy of this viewpoint is the presupposition that the "facts and figures" in Jer are identical with "historical events," or, that they, at least, permit easy access to that which "really happened" during Jeremiah's lifetime. ${ }^{3}$ The ongoing discussion of what "history" is, and how it is intertwined with, even sustained and created by, later interpretation ${ }^{4}$ should make us wary of the great difficulties which lie in the path of any historical reconstruction on the basis of such collections of texts as that of Jer. The fundamental insight of form-critical research, moreover, must not be forgotten: Any given text in the OT more likely than not has been cast into the mold of some conventional

The author gratefully acknowledges the valuable help of the Reverend James L. Pratt who made readable many a Germanic sentence in this essay.

I The most important scholarly monographs in English were written by Th. K. Cheyne (1888); J. Skinner (1922); G. A. Smith (19294); Th. C. Gordon (1931); A. C. Welch (19512); J. Ph. Hyatt (1958); Sheldon H. Blank (1961). Examples of a novel and drama are, respectively: F. Werfel, Hearken unto the Voice; S. Zweig, Jeremiah.

2 Quite naturally psychologists of religion (cf. G. Hölscher, Die Profeten) are interested in biographical facts, as are literary critics (cf. B. Duhm, Israels Propheten). That adherents to a form-critical or traditio-historical approach (cf. G. v. Rad, Theologie des Alten Testaments, II, pp. $213 \mathrm{ff}$.; E. Nielsen, Oral Tradition, pp. $64 \mathrm{ff}$.) should so strongly focus on "accidental historical facts" seems strange, however; cf. G. v. Rad, op. cit., p. 216: "Each of these (confessions of Jeremiah) relates a particular experience."

3 The protests of N. Schmidt (Encycl. Bibl., II, pp. 2372 ff.) and H. G. May (JBL, 61 (1942), pp. $139 \mathrm{ff}$.) against such direct approach are in themselves very much caught up in historical thinking and have not convinced modern scholars; cf. J. Bright, "The Date of the Prose Sermons of Jeremiah," JBL, 70 (1951), pp. $15 \mathrm{ff}$.

4 The old and new quests of the historical Jesus best illustrate the situation of modern scholarship; cf. the books of A. Schweitzer (3rd. Engl. ed. 1957) and J. Robinson (1959) on that matter. 
form of speech. Consequently it does not primarily reflect unique historical events but social and cultic habits and institutions. ${ }^{5}$

The proper way of interpreting a prophetic book, therefore, is to evaluate each layer of its tradition as a witness in its own right as well as a single voice within a choir. Besides looking for redactors and their theology one should carefully watch the small groupings of textual units and their growth and composition. We are not in a position to begin our work at the fountainhead of tradition, but we have to work upstream, closely noting the tributaries right and left. It may well be that the original fountain of one tradition becomes more remote in the process and shrinks in significance relative to the tributaries. Recognizing the multitude of voices in Jer does not diminish their quality as witnesses of God's actions, even if Jeremiah's biography should lose some of its familiar items.

The passage Jer 15 10-21 in itself shows clear signs of long growth. The importance of its complex structure will become apparent when we cautiously try to understand the successive "editors" and "redactors," or, as they are better called, the "interpreters" and "expositors" of preceding witnesses. Form-critical observations may help us occasionally in restoring corrupted lines.

1. The most obvious secondary accretion in Jer 15 10-21 seems to be vss. 13-14. The sudden change of address from Israel to the prophet leads virtually all commentators ${ }^{6}$ to dismiss these verses as a mechanical insertion from Jer $17{ }_{3-4}$. In refusing even to discuss these words as part of ch. 15 they show their disregard for the historical growth of the text. There are strong indications that vss. $13-14$ were deliberately put into the context of the prophet's complaints.

The LXX translator,7 it is true, was already "modern" enough to regard vss. 13-14 a copy of parts of $173_{3-4}$. He rendered the text as a threat against the people, thus announcing God's retaliation for their

5 H. Gunkel, Die Propheten, pp. 110 and 139, rightly warns against looking too soon for prophetic personalities behind prophetic forms. W. Baumgartner, Die Klagegedichte des Jeremia, by subtracting a standard form of complaint-psalm from "Jeremiah's complaints," too easily arrives at the original prophesies of Jeremiah.

6 B. Duhm, F. Giesebrecht, C. H. Cornill, P. Volz, A. Condamin, J. A. Bewer, E. A. Leslie, J. P. Hyatt, W. Rudolph. Commentaries from now on will be quoted only by author's name and page; for bibliographical details see E. A. Leslie, Jeremiah, 1954, pp. $341 \mathrm{ff}$; and W. Rudolph, Jeremia (1958²), pp. xxi ff. Cf. also S. H. Blank, HUCA, 21, 1948, p. 348; G. v. Rad, Evangelische Theologie, 3 (1936), p. 265.

7 Vss. $13 \mathrm{f}$. were in the present position already at that time. The LXX connects

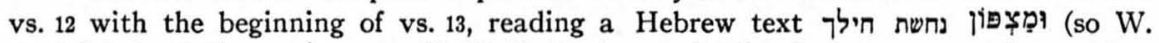

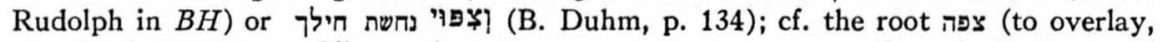
plate), with LXX $\pi \epsilon \rho \iota \beta o ́ \lambda a \iota \nu \nu$ (vs. 12). 
maltreatment of the prophet (cf. LXX in vss. 10-14). Most modern translations follow this version (cf. RSV). He, then, apparently omitted 17 1-4 altogether. Some Hebrew mss follow the same line by reading in vs. 14: "I will let you serve your enemies in a land unknown to you," 8 a familiar prophecy of the exile (cf. Jer 5 19; Deut 28 36; also Jer 16 13; 22 28; 25 11; Deut 28 48, 64). This threat would show God's wrath against Israel in contrast to the favorable answer he bestows on his prophet (MT in vs. 11 ; cf. KJV).

If this tradition of Jer $15{ }_{13-14}$ has a meaningful place within its present context, the unusual rendering of the first line in vs. 14 presented by the bulk of Hebrew mss deserves even closer attention. Instead of the root עבר hiph (to let serve) we find עבר hiph (to let pass),9 a form, which, furthermore, lacks the direct object "you." The MT thus exactly reverses the meaning: "I will let your enemies pass through (into) ${ }^{\text {ro }}$ a land unknown to you," proclaiming the banishment of the foe, and salvation for oppressed Israel. A peculiarity in vss. 13 f. supports this interpretation. Assuming our verses are in some way derived from a longer oracle such as Jer $17{ }_{1-4}$, it must strike us as significant

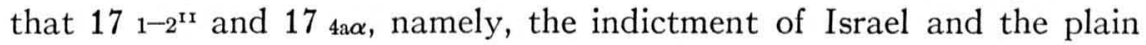
announcement that the people will "let go their heritage," are left out in Jer 15. It seems, therefore, that 15 13-14 has been carefully remodeled into an oracle of promise which once may have read:

Your wealth and treasures I give as spoil, as a price for all your sins throughout your land.

Then I will drive away your enemies into a land unknown to you, for a fire is kindled in my anger, which will burn forever. ${ }^{12}$

8 Biblical translations are my own unless otherwise stated.

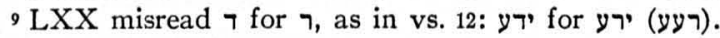

xo The preposition $\sqsupset$ usually designates the area in which things happen (W. Gesenius-E. Kautzsch, Hebräische Grammatik ${ }^{28}, \S 119$ h); yet a sense of direction is quite of ten implied (op. cit., $\S 119$ k. 1; C. Brockelmann, Hebräische Syntax, p. 96). עבר with a following ב occurs, for instance, in Deut 2 30; II Sam 12 31; Ezek 14 15; $473 \mathrm{f}$; Ps 136 14; II Chron 30 5; 36 22; and in the technical phrase "to let go through the fire" (באש): Num 31 23; Deut 18 10; II Kings 16 3; 17 17. The older translation of Jer 15 14a: "I will let you pass through with your enemies ..." (cf. W. Lowth [1719], p. 141; Freedman, p. 109; KJV) presupposes the suffix "you".

II W. Rudolph, p. 96, suggests that 1512 has, in a mutilated form, preserved 17 1-2 (cf. the word "iron" in both passages). This is possible, but unlikely, because of the exact correspondence of words wherever both texts coincide.

12 Once the MT reading of vs. 14a has been accepted several adjustments have to be made in the text of vss. 13 f.: (a) Instead of לא במחיר the affirmative has to be read: Yahweh counts the spoil which he handed over to the enemies (cf. II Kings 21 14; Isa 106 ; Ezek $721 ; 29$ 19) as a payment for Israel's sin; cf. Ps 4413 and the presupposed transaction between God and the enemies in the stereotyped expression "Yahweh sold (Israel)" Judg 2 14; 3 8; 4 2; 10 7; I Sam 12 9; Isa 50 1; Ezek 30 12; Joel 4 8. Cf. especially Isa 42 22-43 4. This understanding requires (b) the omission of both conjunctions in vs. $13 \mathrm{~b}$ and (c) the reading על עד instead of va in (cf. 17 4; Duhm, pp. 143 f.; Rudolph, p. 96; Volz, p. 185). 
Israel's suffering under foreign intrusion is seen as atonement for her sins. Longing thoughts move beyond the plundering of the invaders: When, finally, will her overlords be defeated? When will Yahweh intervene for his people? This is the burden of our oracle. Its position between individual complaints betrays its late placement; so does its outlook on history. Suffering, redemption, liberation all appear in a well-proportioned, theological, and juridical balance. All indications would support the view that vss. $13 \mathrm{f}$. were formulated in the wake of Israel's total defeat in 587 B.c. ${ }^{13}$

What did the editor have in mind when he refashioned the text in this unexpected way? Several motives may have worked together. He wanted to reinterpret the term "enemy" in vs. 11. Yes, Jeremiah's enemies deserved Yahweh's wrath! But now, in the editor's time, Israel's enemies are next in line for punishment. Israel's humiliation has lasted long enough. There is a point when even Yahweh's rightful punishment becomes intolerable. The faithful yearn for relief (cf. Hab 316 and the communal complaint-psalms) as the prophet does in vss. 10, 15-18. In the midst of such stress the editor wants God's reassuring and forgiving word to be heard, not only for the prophet of old (vs. 11, MT) but for his whole people. He wants to counterbalance the harsh rejections $\left(1410 ; 15_{1-4}\right)$ of Israel's pleas and confessions of guilt $\left(14_{7-9,19-22)}\right.$ with this word of hope. Yahweh confirmed the prophet against his enemies. Then and there, already, the restoration of Israel began. Now the time is ripe, after all the terrible judgments of history, for Israel's rehabilitation. The tension between the pronouncements of doom (in 14 1-15 9) and the proclamation of hope (30 f.) finds a preliminary solution in 15 13-14.

Even if our understanding of vss. $13-14$ is only approximately right, we have found in these two verses an example of how individual complaint and private oracle were augmented and thus actualized for the community of Israel.

2. Next we turn to vss. 19-21 because they stand out from their context as an emphatically introduced new oracle and because this personal word of assurance to the prophet seems to be a very wellpreserved entity. Could we possibly look upon vss. 19-21 as another literary layer in the composition of Jer 15 10-21?

Vss. 19-21, formally, are Yahweh's answer to the complaints in vss. 15-18. The "complainer" is rebuked, because his words are "worthless talk." He is first conditionally (19a), then without further discussion $(19 \mathrm{~b}, 20)$ reinstated in his office as Yahweh's mediator, as a bulwark

${ }^{1}$ In Pss 44, 74, 79, and 80 Israel tries to come to grips with the shock of foreign conquest. Our oracle could be understood as an answer to such a communal prayer (cf. Isa 43 3). If this holds true, the editor may have inserted vss. 13-14 as an analogy and continuation to the divine answer in $11 \mathrm{f}$. 
against the rebellious people. The question is: Where do we find the original setting for such an oracle?

The introductory formula (vs. 19: "Therefore, thus said the LORD") ${ }^{14}$ unmistakably indicates that the following word is God's revealed judgment upon the matter. This introduction originally, being an integral part of the message itself, legitimatized a messenger..$^{x s}$ Obviously this cannot be its present purpose at the beginning of this "private" oracle. Here כה אמר יהוה no longer authorizes a person but solemnly emphasizes a divine revelation. The formula has been emptied of its previous meaning. Now it is a literary device, an abstract symbol of theological language, which marks the beginning of Yahweh's holy words. ${ }^{16}$ Furthermore, this introductory formula does not indicate who is the recipient of Yahweh's word. Apparently its author already read Jer $1519 \mathrm{ff}$. in a larger context. Jer 141,11 , and 151 which mention the prophet's name are sufficient for him to illuminate the situation in $1519 \mathrm{ff}$.

The first element of the oracle proper, the conditional reinstatement of the prophet (vs. 19a), in view of its form and content seems to be a reflection of Jer 4 1-2. There the people are offered a blessed life, if they find their way back to Yahweh worship. The breaking of the covenant is not suggested in either passage. ${ }^{17}$ This means that the people and/or

14 "Therefore" (לכן) often marks the juncture between prophetic reflection and the divine word; cf. H. W. Wolff, $Z A W, 52$ (1934), pp. 2, 6; C. Westermann, Grundformen prophetischer Rede, pp. 94, 107. Jer in particular abounds with "messenger formulas"; cf. J. W. Ross, "The Prophet as Jahwe's Messenger," Israel's Prophetic Heritage, pp. 98-107. They are of ten preceded by an emphatic לכן (Jer $514 ; 6$ 21; 7 20; 9 6, $14 ; 1111 ; 1415 ; 18$ 13; 22 18; 23 2, 15, 30, 38; 25 8; 28 16; 29 32; 34 17; 35 17, 19; 36 30; $4215 ; 4411$.

xs Cf. Jer 21 f., 4 f.; 101 f.; 21 3 f.; 29 31; Gen 32 5; cf. especially C. Westermann, op. cit., pp. $70 \mathrm{ff}$.

${ }^{16}$ Some commentators note the awkwardness of the messenger formula in the scheme of personal complaint and oracle (cf. Duhm, p. 136; Cornill, pp. 198 f.) without, however, realizing fully the implications of the transfer of this formula. Cf. the secondary, "theological" use of the phrase especially in Jer 69,$16 ; 1121 ; 131 ; 1719$; $191 ; 221 ; 262 ; 272$. One should compare this with the normal, conversational style of the prophetical, "autobiographical" dialogues (Jer $16,7,9,11 \mathrm{~b}, 12,13 \mathrm{~b}, 14 ; 115 \mathrm{~b}, 6,9$; $136 ; 1411,13,14 ; 151$. Here the introductory words, ואמר ויאמר יהוה אלי and, are short and subordinate. Cf. also the 3rd person "memorabile" Hos 12 ff. (H. W. Wolff, Hosea, Biblischer Kommentar xIv, 1, pp. 7 ff., 71 f.).

${ }^{17}$ Ultimately we have to see the homiletical form of "exhortation for conversion" derived from a legal background. Laws, treaties, contracts were protected by heavy curses, which literally lay in wait for the potential transgressor (cf. Deut $2715 \mathrm{ff}$.). Apparently deuteronomistic theologians not only referred to the transgression of the law to explain the catastrophe of Jerusalem but also amplified the concept to include the counterpart of the curse, namely, the blessings of a life in obedience (cf. Deut $281 \mathrm{ff}$., 3015 ff; Josh 24 15; I Kings 831 ff; Jer 1724 ff; 187 ff; 3817 ff.; 4210 f.; and M. Noth, Gesammelte Studien (1957), pp. $155 \mathrm{ff}$. The pure "conversion speech," then, would be an application of this theological system to the concrete situation of the people already under the curse: It need no longer refer to impending disaster but can look forward to a possible fulfillment of the blessing. Cf. H. W. Wolff, Evangelische Theologie, 5 (1960), 
the prophet are in a state of disgrace. Their apostasy has become manifest. The homiletical conclusion obviously is: one must preach "conversion" and offer the opportunity for return. In a number of parallel passages in Jer, all of which have to be attributed to the deuteronomistic editor of the book, exactly the same situation is presupposed: Jer $7{ }_{5-7}$; $263 ; 2717 ; 2912 \mathrm{f}$; $3515 ; 36$ 3. In numerous other sections, in a somewhat abstract way, the choice between "life and death" is set before the people. Our text (Jer 15 19-21) resembles deuteronomistic thinking not only in this evaluation of the present situation as the moment for decision and in its view of past history as a story of missed opportunities. It also has the characteristic emphasis on man's initial effort (אם־תשוב) to end the alienation from God, an effort which, however, is immediately and surprisingly superseded by God's validifying act (ואשיבך).18

This conditional acceptance of the prophet, considered proper by exilic theologians, may also appear in two other oracles (Jer 125 and 33 3), although the clear structure of an "if" clause with following promise is absent in these cases. The characteristic theology underlying such a "reinstatement upon condition" finally becomes clear in a comparison with accounts of prophetic calls in the OT. Man's refusal to take up God's mission is a standard part of some of these stories. ${ }^{19}$ But nowhere is the prophet considered an apostate figure who has to return before he can be entrusted with his office. It seems that exilic theological anthropology, using the conditional promise of the homiletical address to the congregation, made possible this new concept. The prophet is man. In order to fulfill his holy mission, he, too, has to "turn around" towards Yahweh. ${ }^{20}$

The second, more elaborate part of the oracle, vss. 19b-21, presents quite a changed picture of the prophet. It draws heavily on the formal language of the "prophetic call," thus justifying our comparison above. Yahweh, without further requirement, promises to be with the prophet, to "save and deliver" him (20b, ${ }^{21}$ cf. Gen 28 15, 20; Josh 1 5, 9; Exod 3 12; Judg 616 ; Isa 4110 ; Jer 18 ). God furthermore makes his prophet the pivot on which all of his plans for Israel turn. The prophet will be the

pp. 230 f., n. 18. Earlier references to "conversion" are not yet so theologically formalized (cf. W. L. Holladay, The Root SUBH in the OT, pp. $120 \mathrm{ff}$.

${ }^{18}$ We have to be careful not to identify the deuteronomistic theologoumenon about the necessity of conversion with our theological system of "works" and "grace". A short study of those wordplays which express the interaction between God and man shows the manifold layers of this concept: Jer $1118 ; 1714 ; 207 ; 3118 ; 1621$. In all these cases Yahweh is the initiator as well as the one who warrants the described action. It seems, therefore, that one cannot take the ואשיבך in $1519 \mathrm{a}$ as simply Yahweh's acknowledgement of man's initiative but as a creative act in itself.

19 Cf. Exod 4 10; Judg 6 15; Jer 1 6; W. Zimmerli, Das Buch Ezechiel, Biblischer Kommentar XIII, 1, pp. $16 \mathrm{ff}$.

20 Cf. the theology of the deuteronomist (M. Noth, Utberlieferungsgeschichtliche Studien $^{2}$, pp. 107 ff.; W. L. Holladay, op. cit., pp. 127 f., 132, 153 f.

${ }^{22}$ MT here has an elaborated text; cf. LXX. 
man who accepts or rejects her supplications, will be the object of her scorn. An abstract theological air, akin to deuteronomistic thinking, pervades all of these statements. Detailed observations can only affirm this impression. The basic formula, "I am with you" (אתך אני, 20b), is expanded by a double verbal modification, both in the infinitive construct. ${ }^{22}$ The full phrase which emerges as a result is unique to Jer (1 8, $19 ; 1520 \mathrm{~b} ; 4211$; and 3011 , without the verb נצs). Because it has persistently the same stereotyped form in these different passages ${ }^{23}$ one feels compelled to attribute it to some editorial hand. The promise to "save and deliver" would in itself point to an exilic setting. The unexpected continuation of the wordplay on שוב in vs. 19b at the same time puts the prophet into the position of a decisive mediator and denies him the right to exercise his office. It fits equally well into the context of Jer $716 ; 1_{14} ; 1_{14}$; $(373)$; $(422,20) .{ }^{24}$ The notion of the fundamental and hitherto unbridgeable split between God and his people, consequently also between the people and God's authoritative representative (vs. 20), also conforms with the thinking of exilic Israel (cf. Jer $725 \mathrm{f}$., $27 ; 253$ ff.; $2919 ; 3515 ; 4221 ; 44$ 4. $)^{25}$

Our oracle, Jer 15 19-21, then, shows a late mixture and transformation of elements of form. They are taken from various sources and are all used to express the new and exilic views of God, prophet, and people. The oracle responds to the complaint in vss. 15-18. Had it been united with the complaint when it appeared on the scene of Jer 15?

3. A few text-critical remarks have to be made before discussing vss. 15-18. The first two words in 15, "thou knowest," possibly were inserted after the Greek version had been made, ${ }^{26}$ Jer 1716 and 123 being the prototypes for this amendment. Baumgartner considers these words a possible opening phrase ${ }^{27}$ rather than a secondary connection of the two complaints, Jer 1510 and $15-18$. The first possibility still seems to be the more likely solution.

22 The two verbs $y$ י favorite expression in the language of prayer: Pss $72 ; 2221 \mathrm{f}$; $313 ; 3116 \mathrm{f}$; $3418 \mathrm{f}$.; $593 ; 712 ; 7212 \mathrm{f}$. "Deliverance" becomes the most important theme for many exilic writers and preachers; cf. Ezek 13 21, 23; 34 10, $11 \mathrm{ff}$.; Isa $431 \mathrm{ff}$; $501 \mathrm{ff}$. A sophisticated theology of salvation originates only in these decades after the fall of Jerusalem.

${ }^{23}$ It seems probable that Jer $1{ }^{17-19}$ is a late composition drawn in part from Jer $17-8$, in part from $1519-21$.

${ }^{24}$ Cf. S. Mowinckel, Zur Komposition des Buches Jeremia, pp. 37 f., for a sketch of the view which the deuteronomistic source in Jer held in regard to the prophet. Mowinckel calls it unrealistic and abstract (p. 37).

${ }_{25} \mathrm{Cf}$. the figure hardening the face and heart of the people: (Isa 484 ; Jer 628 ; Ezek 11 19; 36 26; Isa 610 ) and of the prophet (Ezek 38 f.) which indicates the fundamental alienation of God's people.

${ }^{26} \mathrm{Cf}$. the contrary opinion of Duhm, p. 135; Giesebrecht, p. 91; Rothstein (in: E. Kautzsch, Die Heilige Schrift des $A T^{4}$, I, p. 769); Volz, p. 171; Leslie, p. 143; Hyatt, p. 941 .

${ }^{27} \mathrm{~W}$. Baumgartner, op. cit., p. 33. Cf. Ps 139, 1 ff.; but we would expect a de- 
The second textual difficulty in vs. 15 is easier to handle. It is not the verb (תקחני) which has to be eliminated in vs. 15a (as LXX does), but the letters לארך. They are a corrupted dittography of (ב) (ל) (ל) (ל) "(in) thy anger." This leaves us with the original text: "Do not, in thy anger, take me away..." just as in Pss $62 ; 27$ 9; 38 2. Apart from vs. 16, which will be discussed presently, the text is fairly well preserved:
Yahweh, remember me and visit me, and avenge me on my persecutors.
Do not, in thy anger, take me away.
Know that I bore reproach for thy sake.
When thy words were found I ate them, and they became my joy and the delight of my heart,
Because thy name was pronounced over me, Yahweh, God of hosts.
I did not sit in merry company and enjoy myself.
Under thy hand I sat alone because thou filled me with a curse.
Why does my pain last endlessly, why is my wound incurable, resists to be healed?
Thou hast become to me like a deceptive water, which cannot be trusted.

In judging its form and structure the strong resemblance of our text to the complaint-psalms has long been noted. ${ }^{28}$ In the sequence of request, complaint, and reproach represented by vss. $15,17,18$, each has its parallel in the psalms: Pss 62 f.; $59_{2}$ f.; 1064 and $4423 ; 698 ; 8951$ are comparable to the two elements in vs. 15; and Pss 5513 ff.; 88 9, 18; Job 19 13-19; 309 f. to vs. $17 .^{29}$ The direct reproach against God (vs. 18) is also found in Pss 8939 f.; 887 f.; 4410 f., and Job 10 18. The one verse which cannot easily be fitted into this picture presents also the greatest textual difficulties; in LXX vs. 16 continues $15 \mathrm{~b}$ : "Know that for thee I bear reproach 16 from those who despise thy words. Finish them up! But for me thy word shall be merriment and a heart's delight." ${ }_{30}$ The theological concept of enemies despising God's words ${ }^{3 \mathrm{x}}$ seems to be more refined than MT's idea of a prophet eating God's words. Syntactically the MT avoids the long sentence structure. It furthermore

fining object, "Thou knowest $m e$ " or similar (cf. Pss $1014 ; 4010 ; 69$ 6, 20; 142 4; I Chron 17 18; II Chron 630 ).

${ }^{28} \mathrm{Cf}$. W. Baumgartner, op. cit., pp. $39 \mathrm{f}$.: "The affinity to the structure of the complaint-song is obvious. The prophetic viewpoint comes out structurally in the oracle form, substantially in vss. $16,17,19,20$. The passionate reproach vs. $18 \mathrm{~b}$, too, would hardly be possible within the psalms." Cf. G. Hölscher, op. cit., p. 397; H. Schmidt, p. 272; H. Gunkel (introduction to H. Schmidt, Die Schriften des Alten Testaments II, 2, p. 1xxii).

29 "Sitting alone" is a description of the seclusion which results from being punished by God (cf. Lam 11 ; Job 2 8; Lev 1346 ). "Before your hand" does not imply a compulsion to prophesy as in Ezek $13 ; 314$; it simply states that God is the author of the suffering (cf. Ps 32 4; Job $1921 ; 23$ 2).

30 The Hebrew original which LXX may have used shows only three minor differences from MT. Cf. apparatus criticus of $B H$.

${ }^{31}$ Cf. Ps 107 11; Isa 5 24; Jer 2317 (LXX!); Jer 5 13; $610 ; 89$. 
offers the more difficult reading of the text, so it may be older than LXX. The vocabulary used in both versions seems very stereotyped..$^{32}$

While the "eating of the divine word," described in MT, as well as the LXX's "contempt of God's word," 33 still can be understood in the context of a complaint-psalm, the individual's assertion in vs. 16b, to have been taken into possession by Yahweh, certainly refers to a prophetic call. The evidence suggests that this formula in its theological meaning first was used in exilic and postexilic times to express the enduring election of Israel and her peculiar relationship to God. ${ }^{34}$ Later it would seem to have been used to indicate the individual's introduction into the community of the faithful (cf. Jer 15 16; Isa 43 7), although the evidence is scant.

If this assumption is correct, we have found a clue to the setting of vss. 15-18. A writer at home in prophetic theology probably augmented an older complaint-psalm by inserting or rephrasing vs. 16. Possibly it was the same hand which wrote vss. 19-21, augmented 16, and put the whole passage $(15-21)$ into its present place. There is no doubt that this happened with a view towards the terrible doom announced in $141-$ 15 4. The prophet's personal fate and suffering are drawn into the picture. More than that; the prophet's life is brought into relation with the people's sin and punishment. Their rebellion against Yahweh is the immediate cause of his distress. The prophet's suffering is representative of God's own suffering. So the complaint- and answer-liturgy in $147 \mathrm{ff}$. and the complaint and oracle in 1510 ff. mark opposite but corresponding rôles in one drama.

This does not exclude the possibility that Jer $1510 \mathrm{ff}$. may have been read later, as the insertion 13-14 suggests, as a communal complaint corresponding to the announcement of doom in $155_{5-9.3^{35}}$ Such an understanding of $1510 \mathrm{fr}$. could possibly arise in analogy to text compositions in which oracles of doom are followed by an added cry of anguish (cf. Jer 4 13-18, 19-21; 10 17-18, 19-21; Isa 21 2, 3-4; Hos $11_{5-7,8-9)}$.

4. The last complex unit within our passage is vss. 10-12. Again we find two textual traditions, each of which permits numerous different

32 "Joy and delight" (cf. Jer $734 ; 169 ; 25$ 10; 31 7, 13; 33 9, 11; Isa 22 13; 35 10; 51 3, 11; Ps 51 10; also Pss 4 8; 119 111); "called by thy name," (cf. Jer 7 10, 11, 14, 30; 32 34; 34 15; 14 9; 25 29; Amos 9 12; Deut 28 10; I Kings 8 43; Isa 63 19; Dan 918 f; II Chron 7 14).

${ }_{33}$ The word of God would be the favorable oracle a supplicant has received (W. Baumgartner, op. cit., p. 35; cf. Ps 35 3). B. Duhm (p. 135) views the MT reading as a shallow remembrance of Ezek $28 \mathrm{ff}$.

34 The original juridic meaning is apparent in II Sam 12 28; Isa 4 1; Ezra 261. Calling out the name of a proprietor over his property has to be distinguished from the phrase, to "call somebody by his name" (cf. Isa 431 ; Gen 48 6; Deut 3 14). That Yahweh's name has been pronounced over Israel, the temple, the city becomes a fixed theological confession (נקרא שם יהוה על) in exilic times. The older tradition uses a similar formula only in regard to the ark (II Sam 62 ).

3s So Chr. Barth, Einführung in die Psalmen, p. 22. 
interpretations. The crucial point is the reading of one single letter in the first word of vs. 11. LXX apparently goes back to a Hebrew אמן; MT on the contrary still shows in all old Mss uninfluenced by LXX אמר ("he spoke"). We consider the Hebrew text to be older than LXX, and therefore understand 11-12 as God's response towards the prophet's complaint. ${ }^{36}$

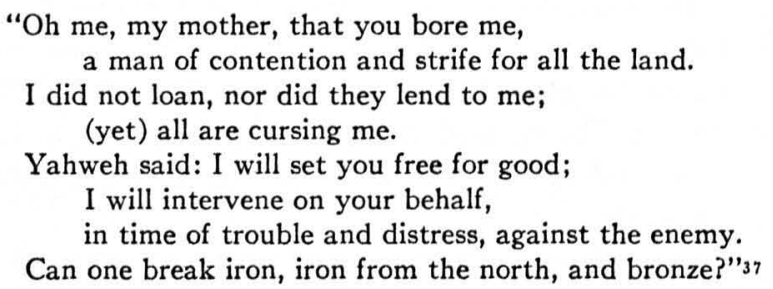

LXX after misreading the אמר interpreted the following conditional oath as a continuation of the declaration of innocence in accord with Jer $1716 ; 1820$.

As it stands in Hebrew, our text gives no evidence whatsoever that it might be speaking about a prophet or prophetic office. Rather it seems to be a normal complaint with a following salvation oracle,,$^{38}$ although vs. 10, contrary to usual practice, is composed of a mourning cry, ${ }^{39}$ a declaration of innocence (cf. Ps $26_{4-6}$; Job $23_{11-12}$ ), and a complaint about unjust treatment. The form elements in 10 and $11 \mathrm{f}$. seem to be intricately connected. They probably came into writing as a unit. The lack of theological refinement and the brevity and compactness of our verses make them appear more archaic than their counterpart, vss. 15-21. So we may assume that in 10-12 we have finally reached the oldest elements in the composition of Jer 15 10-21, and the question which now arises, why and when vss. 10-12 came to Jer 15 , is intimately tied up with the larger question of composition and purpose of the whole passage.

${ }^{36}$ Most exegetes follow the LXX; cf. RSV. Too many arguments speak against its originality, however: 1. "Amen" is an individual (I Kings 136 ; Num 5 22; Jer 11 ; 28 6) or, more commonly, a communal liturgical response (cf. Deut 2715 ff.; Ps 106 48; Neh 5 13; 8 6; I Chron 16 36; Pss 41 14; 72 19; 89 53), a confirmation of an authoritative pronouncement. It cannot very well be considered a reaction to a confession of innocence (vs. 10b). Sheldon Blank's line of argument (Jeremiah, Man and Prophet, p. 241), "Here the word would mean something like 'indeed," "would better support our conclusion than his own. 2. A declaration of innocence itself can appear in the form of a conditional self-curse (Ps 7 4-6; Job 31 5-8, 9-10), but with a normal statement of consequence in case of perjury (Ps 76 ; Job 31 8, 10) and without the artificial "amen." 3. LXX is familiar with the liturgical "amen" and tends to read it into the Hebrew text (cf. Jer 3 19, LXX vs. MT).

${ }^{37}$ Vss. 11-12 are badly preserved. For the discussion of the text see the commentaries. Our translation follows mainly Baumgartner's, op. cit., p. 61.

${ }^{38}$ Cf. esp. J. Begrich, $Z A W, 52$ (1934), pp. 81 ff. Gunkel-Begrich, op. cit., pp. 246 f.

39 Cf. the dirge style (H. Jahnow, SupplZAW, 36 [1923], pp. 83 ff.) and Ps 120 5; Isa $65 ; 24$ 16; Jer 4 31; 10 19; 453. 
To determine the present meaning of our whole passage we have to look for its position in its larger context. The arrangement of two complaints, plus an answer and the careful editing to fit the prophetic context especially of the second unit (15-21), should make it clear that Jer 15 10-21 was not placed there by accident, as some commentators seem to believe..$^{\circ}$ At least in the mind of some late editor the larger composition including our text is the combination of chs. 14 and 15 . The full revelation formula ${ }^{4 \mathrm{I}}$ occurs at the beginning of ch. 14. It is followed by a series of introductory expressions in simple narrative style $(1411,14 ; 151)$. Only in 161 does the solemn formula, "the word of Yahweh came to me," begin a new section. ${ }^{42}$ Although this division is clearly late, associated with the deuteronomistic edition of Jer, ${ }^{43}$ it is confirmed by examination of the text itself. Ch. 13, as well as ch. 16, contains for the most part divine announcements, unilateral declarations of doom. Jer $14 \mathrm{f}$., on the other hand, consists essentially of material in the form of a dialogue.

1. The basic material in $14_{1-15_{4}}$ is in the form of two introductory laments and two complaints of the people. The laments describe, respectively, the devastating effects of a drought and the results of a

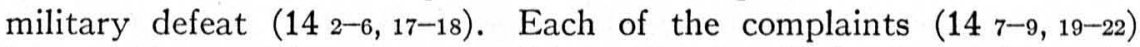
is complemented by an oracle $(1410 ; 151-4)$. Obviously, at least the answer to the second complaint is a later addition; in its introductory line ("... the Lord said to me") it creates the false impression that the prophet had been speaking the preceding complaint. ${ }^{44}$ But the use of the first person plural in 14 19-22 excludes this assumption. The oracle answer in itself is a complex unit, ${ }^{45}$ consisting of a final rejection of the people's complaint (15 1; cf. Ezek 1414 ), the people's inquiry about

$4^{\circ} \mathrm{Cf}$. Duhm, p. 134 ; Rudolph, p. 97.

${ }^{4}$ In Jer the revelation formula composed of some form of the verb היה and the construct relationship דבר יהוה seems, as in Ezek, to divide the text material into revelatory acts. The formula is theologically charged when it describes the total prophetic activity (cf. Jer 251,3 ). It occasionally refers to an individual revelatory act (cf. Jer 13 8; 28 12; 29 30). Cf. O. Grether, Name und Wort Gottes im AT, SupplZAW, 64 (1934), pp. $67 \mathrm{ff}$., $84 \mathrm{ff}$.

$4^{2}$ Both formulas, that of 141 and 161 , are textually dubious: LXX translates more or less different formulations. We assume, however, that the MT tradition is older, and that LXX no longer understood the meaning of this systematization. In MT apparently Jer $2-6 ; 7-10 ; 11-12 ; 13 ; 16-17 ; 18-20 ; 21-23 ; 24 ; 25$ are likewise considered "kerygmatic units" by the redactor. LXX betrays its lack of interest in this order by omitting the formula in 21 and 71 .

43 Cf. S. Mowinckel, op. cit., pp. $31 \mathrm{f}$.

${ }^{44} \mathrm{Cf}$. Duhm, pp. $130 \mathrm{f}$. Does the editor look back to 1417 , regarding $17-22$ as one prophetic announcement?

${ }_{45}$ Hyatt, p. 936: "In its present form this passage is from the Deuteronomic editor. ..." Cf. Rudolph, p. 95; Mowinckel, op. cit., pp. $22 \mathrm{f}$. 
their way (15 2; cf. Jer 421 f.; Ezek 141 f.; 201 f.; 3330 f.), and another pronouncement of doom on account of the sins of Manasseh (15 3 f.; cf. Deut 28 25; II Kings 23 26). For us it is important to note that the prophet throughout these verses is seen as the fully commissioned representative of Yahweh. We found the same image in 15 19-21. That the editor of this composition is not content with just describing the people's rôle is proven by an insertion which also regards the prophet as the decisive supplicant and mediator. The passage $1411-16$, clearly deuteronomistic in character and theme, ${ }^{46}$ was drawn into this context precisely because of its understanding of the prophetic office as a mediatory one (cf. Jer $410 ; 716 ; 11_{14} ; 422$ ff.). So we may say that in $141-$ 154 the writer of Jer adopts and reconstructs the well-known form of a complaint liturgy ${ }^{47}$ and makes certain that the form is repeated once, perhaps because the twofold expression of complaint with an oracle answer was a standard one. $4^{8} \mathrm{He}$ places great emphasis on his concept of mediation. The prophet not only intercedes for the people but also executes Yahweh's will.

Most of the examples of a communal complaint liturgy preserved in the OT have favorable oracle answers. In Jer $141 \mathrm{ff}$. the answer is unconditionally negative. Israel's complaints are not accepted. The prophet's intercession is refuted. This underscores the futility of Israel's hope. Even the rejection of the people's plea in Hos 64 ff. does not match the harshness of our passage. Conceivably the unyielding judgment in Jer shows or preserves the insight won after the fall of Jerusalem: supplication and intercession had not saved Israel, in spite of all covenant assurances.

Looking from Jer $14_{1-15} 4$ to our passage 15 10-21 we can ascertain already the formal and substantial affinities between them. The communal complaint-answer dialogue corresponds to the prophet's complaints and the oracle answers in $1510 \mathrm{ff}$; the introduction of the prophet in 1411,13 , and $15_{1-4}$ as an intercessor forshadows his rôle in 15 19-21. Since the latest integral parts in the composition 14 1-154, namely, $15_{1-4}$ (which only makes the "liturgy" complete) are definitely exilic, we have to conclude that the whole composition is of that date.49 Consequently the final arrangement of 15 10-21, patterned as we shall see on $141-15_{4}$, cannot be of an earlier date.

2. Jer 15 5-9 does not seem to fit into this picture. The passage starts out as a lament in dirge style, spoken by Yahweh or the prophet for the desolate city of Jerusalem (vs. 5; cf. Isa 5119 f.; Nah 3 7; Lam 12 ,

${ }^{46}$ Cf. Hyatt, p. 933; Mowinckel, op. cit., pp. $36 \mathrm{ff}$.

47 Cf. Gunkel-Begrich, op. cit., pp. $136 \mathrm{ff}$., $408 \mathrm{ff}$., $246 \mathrm{f}$.

${ }^{8}$ Cf. Gunkel-Begrich, op. cit., p. 138; H. Gunkel, $Z A W, 42$ (1924), pp. $190 \mathrm{ff}$., $194 \mathrm{f}$; H. Gunkel "The Close of Micah," What Remains of the OT, pp. $142 \mathrm{ff}$.

49 Cf. S. Mowinckel, op. cit., pp. 22 f. 
17; 215 ; Amos 5 2). But the rest of 155 ff. is neither a lament nor a complaint. $^{50}$ In vs. 6 another element appears: Yahweh addresses himself directly to Jerusalem, first in an indictment (6a), then in an affirmation of his punishment (6b). Vs. 6 as a whole seems to be spoken in response to 5 . The reason for the mourning in 5 is nothing but the deserved punishment from the Lord. The dialogue form, then, seems to be preserved in this unit, although the first part is no longer a complaint, but a postfactum lament. Vss. 7-9 in a way seem to be patterned like $6 \mathrm{~b}$ : Yahweh enumerates the punishments which he has already inflicted upon the people, and at the very end turns to even further threats against the remnant (9b; cf. $6 \mathrm{~b}$, "I am weary of relenting"). But vss. 7-9 lack the 2nd person address. They speak about the people rather than the city of Jerusalem. They also lack the response character of vs. 6 . So we may consider these verses as an expansion of the thoughts contained in 6.

Jer $15_{5-6}$ would then in a final dialogue (lament-answer) conclude and reinforce the picture of destruction painted in the liturgy of $14_{1-}$ 15 4. The whole passage $\left(15_{5-9}\right)$, dialogue plus expansion, speaks from the perspective of the completed devastation with some last catastrophes still to come. This sounds like a situation which might have existed after the first Babylonian conquest in 597 B.C. In this case it would be likely that the composer of the liturgy Jer $141 \mathrm{ff}$. used old material to bring to a close his sketch about the futility of Israel's complaints.

3. Jer 15 10-21 finally seems to be exactly modeled after the repentance liturgy in 14 1-15 4. According to our reconstruction of the text the same twofold cycle ${ }^{\text {sI }}$ of complaint and answer has become visible. Apparently the composer used one old unit (vss. 10-12) and augmented the words of another standard complaint by one line as well as by an oracle answer (vss. 15-21) in order to give his composition the standard two parts. ${ }^{52}$ Since the oracle answer (vss. 19-21) proved to be of deuteronomistic character, we may even assume that the same hand which worked out the twofold liturgy in 14 1-15 4 completed the composition by adding the twofold complaint of the prophet himself. If this is correct - and the formal analysis of 15 10-21 would support such a view - then we have to ask for the meaning of this passage as it follows the people's complaint-liturgy. The composer, in taking such

so Cf. H. Jahnow, Das hebräische Leichenlied, SupplZAW, 36 (1923), pp. 102 f., $168 \mathrm{ff}$., $183 \mathrm{ff}$. It would be profitable to distinguish between lament and complaint: a lament bemoans a tragedy which cannot be reversed, while a complaint entreats God for help in the midst of tribulation.

${ }^{5}$ Cf. Gunkel-Begrich, op. cit., p. 138.

${ }^{52} \mathrm{Cf}$. Gunkel-Begrich, op. cit., p. 409: The individual complaint-psalm cannot be considered the basis for liturgies of recurring complaint and answer. This observation seems to be confirmed in our text. 
pains to demonstrate the parallelism between prophet and people, certainly saw a deep theological necessity for so doing.

Since the deuteronomist's view is most clearly expressed in his own additions to the composition, it is in the light of the concluding vss. 19-21 that we now have to interpret 15 10-21. Now all the attention is focused on the prophet and his relationship to the people. Neither the complaints in vss. $10,15-18^{53}$ nor the oracle answer in $11 \mathrm{f}$. (as far as it is recognizable) said anything like vss. 19-21 about the prophet himself. It is not so much "biographical" data which attracted the interest of the deuteronomist. The individual traits of the preceding complaints fade into the background (cf. e. g., 10b, 17a) and are not taken up in Yahweh's response. "Private" afflictions are no longer important. It is the divine office and Jeremiah, the authorized officeholder, that occupy the deuteronomist's mind (cf. especially vs. 20a). The fate of Israel, according to the exilic view of history, has been decided by her hostile attitude to the prophetic office. ${ }^{54}$ It had been the vessel of Yahweh's word; it had been authorized to grant salvation or reject the impenitent people (vss. 19b, 20a). It had been vested with Yahweh's own authority. No wonder that the officeholder can venture bitter castigations (cf. vs. 18b: "Thou hast become to me like a deceptive water, which cannot be trusted") without being consumed by Yahweh's wrath. No wonder that he has to suffer in consequence of the people's rebellion against Yahweh's guidance (vs. 20a). All the preceding complaints now have to be understood in the light of Israel's attack against the prophet. In all this the deuteronomist sees the prophetic commissioner involved in the controversy between Yahweh and his people (cf. $1411 \mathrm{ff}$.) but on Yahweh's side.

The divine office is, according to the deuteronomist, occupied by a weak mortal, who suffers, prays, loses the right track (cf. especially vs. 19a). This is the reason why the deuteronomist introduces "prophetic" complaints (vss. 10,15-18) in the same way he tells about the people's laments and complaints $(142-9,19-22)$. The "historical" Jeremiah, in his opinion, does not live up to the majestic task he is called to perform. In a sense he remains a member of these apostate people who lament, confess their sins - and are rejected (14 2 ff.). Therefore even the prophet has to be admonished to "turn back" (vs. 19a; cf. 41 f.).

But all we have said so far must be seen before a larger background. The deuteronomist does not confine himself to presenting to his reader a divine office and a prophet struggling to fill it. The ultimate concern of our final editor rests with the people. He wrestled with the problem of

53 Vs. 16 is an exception because it was reformulated by the deuteronomist.

$54 \mathrm{Cf}$. the similar position of the prophet in deuteronomistic historical writings; M. Noth, Überlieferungsgeschichtliche Studien, pp. $78 \mathrm{ff}$. 
their election and rejection in 14 2-15 9. Historical events had demonstrated that the incomprehensible could happen: God had put Israel out of his sight (15 1). Prophetic intervention had been useless (14 $11 \mathrm{fr}$.). Was this the absolute end for Yahweh's people? The deuteronomist answers "no," because the prophet himself, as a member of this weak and unreliable Israel, becomes a paradigmatic figure of salvation. " . . I am with you to save and deliver you..." (vs. 20b) is the final pronouncement over the prophet. Thus Jer $14 \mathrm{f}$. ends on a more hopeful note. One man has found grace with Yahweh. ${ }^{55}$ This is a ray of light which shines out in the darkness of the unconditional doom expressed in $142-159$.

\section{III}

Our literary and form-critical analysis attempted to show that Jer $14 \mathrm{f}$. is an organic textual unit composed over a long period of time. The central theme of the whole passage is the suffering of the people and Yahweh's response to their cry, be it the communal laments in ch. 14 or the individual's complaints in ch. $1510 \mathrm{ff}$. The linking together of lament or complaint and divine oracle certainly reflects the liturgical pattern of prayer and oracle answer although it is by no means clear whether such "prophetic liturgies" had been "performed" in actual worship or whether they were only literary products.

The dating of a complex unit like Jer $14 \mathrm{f}$. poses great difficulties. In its final form the composition was finished in exilic times. Deuteronomistic thinking has left its impression on it. The original cycle (Jer 14 2-15 9) with its grim outlook into the future could possibly go back to a time before the fall of Jerusalem. More probably it reflects the sentiment after the fall of the city. It is a deuteronomistic rationalization that nothing could in the end prevent the final destruction because of the "sin of Manasseh" (cf. 15 ; $1411 \mathrm{fr}$ ).

The deuteronomist has had a similarly decisive influence on the following passage. This second, "prophetic" round of complaint and answer, which mirrors the structure of the preceding communal part, was not completed until late exilic times. There are good reasons to believe that the deuteronomist can be credited with the composition of $1510-21$, in contrast to $142-159$ where deuteronomistic passages seem to have been inserted into an already existing liturgy.

Of course, this sketch of the literary development of Jer $14 \mathrm{f}$. does not say very much about the authors of its individual literary com-

ss Some Jeremiah narratives (cf. $26 ; 28 ; 37 ; 38$ ) also could be called stories of paradigmatic salvation rather than "passion stories" (cf. H. Kremers, Evangelische Theologie, 13, [1953], pp. 122 ff.). 
ponents. Answers to direct questions in this regard must be extremely hypothetical. The individual words are not signed by any writer, nor does the fact that we find them collected in a book ascribed to the prophet Jeremiah guarantee their "authenticity." There is a slight possibility that the oldest parts of the first cycle $\left(1410 ; 155_{-9}\right)$ are Jeremianic, because they contain prophesies similar to those in Jer 2, 4-6, and 8-9 which have the best claim to have originated with the prophet himself. Even the oldest part of the second cycle (15 10 f.) hardly betrays any prophetic origin.

Our main concern has been to trace the growth of Jer 15 10-21. To summarize the results: The oldest layer within this passage is vss. $10 \mathrm{f}$., an individual complaint with a priestly oracle of assurance. This unit has been incorporated into Jer probably because the editor, knowing already about the sufferings of Jeremiah from the "biographical" narratives, saw in them an analogy to the agony of the people (ch. 14). It was possibly the same deuteronomistic editor who augmented this first complaint-answer dialogue with a second one (vss. 15-21) and so completed the cultic pattern. By doing so he also intended to make plain the crucial rôle Jeremiah played for the people of Israel. We noticed the strong deuteronomistic coloring of all the concepts involved. At a third stage of growth another hand inserted vss. 13-14 to turn attention back to Israel in her distress. This last editor not only refers us back to the central theme of the composition Jer $14 \mathrm{f}$. He also makes it explicit that the whole kerygmatic unit ends in a veiled promise for Yahweh's people. So he is justified in announcing an end of Israel's oppression and the dispersal of her enemies.

Among the many questions which remain unsolved one of the most urgent is this: Can the other individual complaints in Jer also be explained as compositive elements in some larger textual unit? Can the complaints in Jer thus be shown to be later insertions into an existing collection of prophesies? 